\title{
The social structure of Brexit and the crisis of globalisation
}

\author{
Towards an analysis of the disjuncture
}

\author{
Emma Dowling
}

Received: 15 October 2020 / Accepted: 12 December 2020 / Published online: 17 March 2021

(C) The Author(s) 2021

\begin{abstract}
Despite much protracted debate, there is still no consensus among social scientists as to why a majority of Britons voted to leave the European Union in June 2016. This paper constructs a sociology of Brexit and seeks to interpret the fractious constellations on either side of the Brexit disjuncture. Taking as its point of the departure the resurgence of sociological interest in class in the wake of Brexit and with the rise of right-wing populisms in recent years, the paper argues for a compositional, intersectional and historically dynamic class analysis of Brexit's political fault-lines within the context of Britain's neoliberal restructuring. An analytical framework is proposed with which to explain how neoliberal globalisation has transformed British society and its concomitant class relations, accounting for the disarticulation of previous political allegiances. The paper explains the Brexit vote in terms of central social-structural components, including class, ethnicity, geographical region, age, and educational attainment. It is argued that the vote in 2016 to leave the European Union is best interpreted as a residue of a post-war class compromise, while the vote to remain in the European Union reflects a class constellation recomposed by neoliberal globalisation, which is unstable and in crisis. The article concludes with a discussion of the overall implications of the argument presented for a sociological reading of Brexit.
\end{abstract}

Keywords Brexit · Class analysis - Intersectionality $\cdot$ Affective structure $\cdot$ Voting behaviour $\cdot$ Crisis of globalisation

E. Dowling $(\bowtie)$

Department of Sociology, University of Vienna, Rooseveltplatz 2, 1090 Vienna, Austria

E-Mail: emma.dowling@univie.ac.at 


\section{Die Soziologie des Brexit und die Krise der Globalisierung}

Eine Analyse sozialstrukturellerer Disjunktionen

Zusammenfassung Trotz langwieriger Debatten gibt es unter Sozialwissenschaftler*innen immer noch keinen Konsens darüber, warum eine Mehrheit der Brit*innen im EU-Referendum vom Juni 2016 für den Austritt aus der Europäischen Union gestimmt hat. Dieser Artikel untersucht die sozialstrukturellen Wählerkonstellationen auf beiden Seiten der Brexit-Disjunktion, auf der Leave- wie auf der RemainSeite. Ausgehend vom Wiederaufleben des soziologischen Interesses an Klassenverhältnissen im Zuge des Brexit und des Aufstiegs des Rechtspopulismus in den letzten Jahren plädiert der Beitrag für eine intersektionale und historisch dynamische Klassenanalyse der politischen Bruchlinien des Brexit im Kontext der neoliberalen Umstrukturierung Großbritanniens. Es wird ein analytischer Rahmen vorgelegt, der erklärt, wie die neoliberale Globalisierung sowohl Klassenverhältnisse als auch politische Zugehörigkeiten verändert hat. Anders als die Brexit-Analysen, die BrexitBefürwortende und Brexit-Gegner*innen in Globalisierungsverlierer*innen und -gewinner*innen unterteilen, untersucht der Artikel eine heterogene Zusammensetzung zentraler sozialstruktureller Komponenten wie Einkommen, Ethnizität, geografische Region, Alter und Bildungsniveau, die keine einfache Aufteilung in Gewinner*innen und Verlierer*innen zulässt. Es wird argumentiert, dass die Brexit-Befürwortung am besten als Residuum eines fordistisch-keynesianistischen Klassenkompromisses der Nachkriegszeit verstanden werden kann, während das Votum für den Verbleib in der Europäischen Union auf eine durch die neoliberale Globalisierung neu konfigurierte Klassenzusammensetzung hinweist, die aber instabil und in der Krise ist. Im Fazit werden die Implikationen dieser sozialstrukturellen Interpretation des EUReferendums von 2016 zusammengefasst und diskutiert.

Zusammenfassung Brexit - Klassenanalyse - Wahlanalyse - Affektive Struktur · Intersektionalität · Krise der Globalisierung

Britain's vote to leave the European Union in June 2016 after 43 years of membership was a close shave: $48 \%$ of voters opted for remaining in the European Union and 52\% voted to leave. This outcome was the expression of a disjuncture in British society linked to the rise of populisms in advanced capitalist societies as an expression of a crisis of legitimacy of institutions and the crisis of globalisation as a progressive narrative. Yet, existing interpretations of the referendum's outcome conflict. On the one hand, the vote for Brexit (Leave) is seen as a protest by the 'losers of globalisation' seeking to punish an establishment that left them behind (Hobolt 2016; McKenzie 2016). Derivative of this is then a stylisation of voters against Brexit (Remain) as the 'winners of globalisation', hand in hand with a characterisation of Leave voters as nativist conservatives and Remain voters as the bearers of liberal, progressive and cosmopolitan values (Inglehart and Norris 2016). While some see a tight coupling of economic and cultural motives, others deny any clear economic basis. They argue that the Brexit vote, like the vote for President Donald Trump in the United States, was informed by identity and cultural values 
alone (Kaufmann 2016). On the other hand, critics have argued that the Brexit vote was not actually a vote by the 'left-behind' at all, but a defence of (relative) privilege (Dorling and Tomlinson 2019) and have criticised the downplaying of racism and xenophobia as the motivating force of Brexit (Emejulu 2016; Bhambra 2016). There are indeed also analyses that caution against simplistic readings of the far more contradictory constellations of social forces and political disaffections that characterise the disjuncture (O'Reilly et al. 2016, p. 809). Nonetheless, most research has sought to explain the vote for Brexit; less effort has been expended on explaining the vote against it, while also seeking to understand how material and cultural factors intersect.

In this article I probe the possibility of an internal coherence to the motley crew of voters on either side of the vote and suggest that both sides cohere in a fractious but intelligible constellation. First I attend to the question of who voted for Brexit and why, piecing together the social structure of the Leave vote and explaining the significance of the crisis of neoliberal globalisation. I then turn to the composition of the Remain vote and analyse the recomposition of class relations due to neoliberal globalisation, before concluding with a discussion of the overall implications of my argument for a sociological analysis of the current crisis. With the concept of disjuncture and with reference to the tradition of conjunctural analysis I describe something more than a mere split and give expression to how forms of social cohesion and political allegiance have come undone due to social and economic transformations. ${ }^{1}$ However, where the notion of conjuncture emphasises the coming together of particular class contradictions, my focus is on the falling apart of previous class constellations. I argue that the Leave vote coheres as a residue of post-war class compromise in an effort to reactivate a bygone compromise in response to the present crisis, while the Remain vote reflects the breakdown of a class constellation that emerged with neoliberal globalisation. ${ }^{2}$ The disjuncture of Brexit articulates the ongoing crisis of neoliberal globalisation, with 'winners' and 'losers' of globalisation on either side of the constellation. The grievances and demands of these sides are politically pitted against one another in projects that offer little hope to correct the losses, or to establish solidarity between the disadvantaged groups.

\section{Analysing the Brexit complex}

Reading Britain's 2016 EU-referendum sociologically means assessing events from the perspective of the social formation in which they occurred. This means (1) tracing the social, economic and cultural conditions that prepared the ground for the outcome, (2) assessing the social structure and stratification of British society and

\footnotetext{
1 See for example Koivisto and Lahtinen (2012, p. 276); R. Williams (1977); Hall et al. (2015 [1978]); J. Clarke (2010).

2 For reasons of scope, my focus is on England and excludes an analysis of events in other parts of the Union. See for example on Northern Ireland: Gormley-Heenan and Aughey (2017), on Wales: Jones (2017) and on Scotland: Knight (2017).
} 
attending to the subjective understandings of social location, lived experiences and political expectations, (3) explaining how these find their articulation in particular political discourses and actions and (4) contextualising the social conflicts and class compromises (past and present) that shape the particular social formation.

One of the most interesting outcomes of the Brexit vote from a sociological perspective is the resurgence of the category of class: everyone seems to agree that class mattered, yet the conceptions of class deployed have been limited. Either they have rested on highly problematic notions of a racialised 'white working class' standing in for a working class in general, as has been criticised (Bhambra 2016; Shilliam 2018; Virdee and McGeever 2017); or the working class is rendered synonymous with a particular social identity, namely a male industrial proletariat of yore, as has also been criticised (Dowling et al. 2017; J. Clarke 2020b). However, class cannot be reduced to social identity and even socio-economic positions are in constant flux. Therefore, as J. Clarke (2020a) argues, a more historically dynamic class analysis is required. I suggest that the following four elements of class analysis can be brought together to provide a framework for investigating of the shifts in economic interests and cultural values as a result of the restructuring of class relations. First, a compositional class analysis that studies how classes and class relations change over time due to socio-economic transformations with regard to labour process restructuring, cultures of work and employment, social subjectivities, business models and government policies (Milburn 2019, p. 23ff.). Second, an analysis of the historical formations of class compromises, in which the contending forces of capital and labour "find a way to actively cooperate [that] open[s] up some space for [them] to better realise their interests than is possible by simply extracting concessions through confrontation" (Wright 2012, p. 2-3); as well an analysis of cross-class alliances that fuse different, antagonistic class realities in a common political consensus (Hall et al. 2015 [1978], p. 156). Third, an intersectional analysis (Hill-Collins 2009; Whitehead 2016) that accounts for the linkages of class with other social structural categories such as gender, ethnicity, age and geographical region, and the ways in which these intersections not only reflect economic interests, but also particular socio-cultural values congealed in materially anchored social subjectivities. Fourth, an attention to the ways in which past social formations may continue to exert a residual influence on the present and how emerging formations may not have yet stabilised, if they stabilise at all (R. Williams 1977, p. 125ff.).

Social groups do not act politically merely on the basis of their socio-economic position, nor do cultural values alone influence political allegiances. Individuals make sense of the world on the basis of their lived social experiences and the political narratives that render lived social experiences intelligible. Processes of political signification (Thompson 1978; Flecker et al. 2007; Pineault 2016) involve meaning-making shaped by the political views circulating in proximity-whether real or virtual, such as in the much implored online 'echo chambers' of social media (Sunstein 2009). Therefore it is instructive to analyse the affective-discursive structures of the Leave and Remain voting patterns that made voting one way or another a viable option. Affective-discursive structures are relatively stable sets of interlocking relations that operate to produce certain feelings, sensations and 
motivations, thus augmenting or diminishing an individual's capacity to act. ${ }^{3}$ They have an emotional, embodied and non-verbal intelligibility, but they also connect to discourses of signification and are material in how they shape social relations and subjectivities. An attention to affective-discursive structures enables a consideration of felt and sensed dimensions as opposed to mere rational decision-making with regard to political actions. Feelings such as anger, frustration, resentment, anxiety or hope can be given political meaning.

With this framework in mind we can unpack what we might call the Brexit Complex, the processes of political signification that led to the outcome of the referendum. Leave was fuelled by social anxiety over cultural and economic decline that converged in figures such as the 'unaccountable EU-technocrat' or the 'immigrant threatening our way of life and resources.' Such scapegoating is a form of ideological displacement (Hall et al. 2015 [1978], p. 29), where threats to social (in this case: national) cohesion are conceived of as emanating solely from the outside. This kind of externalisation deflects from the internal structural conditions of crisis that require political redress. On the other hand, Remain was inextricably linked with the maintenance of a political and economic status quo of neoliberal crisis. Yet, while disaffection to this status quo was mounting, no viable alternative to the false solution of Brexit able to tackle the problems of the status quo was put forward. ${ }^{4}$ The different parts of the Remain camp were simply too heterogeneous in their approaches, which included radical left as well as modest reformist and liberalmarket ideas, including the status quo policies of the Cameron era. Making apparent another facet of disjuncture, namely a temporal one, it is only in the aftermath of the referendum that an active political movement in favour of EU membership has garnered momentum. However, the social and economic problems driving the crisis of neoliberal globalisation have not been addressed by leading political forces, including the Labour party.

\section{Voting to leave}

There were four elements to the affective-discursive structure of the Leave campaigns. First, the threat to identity and security, characterised by the charge that EU-migration is a burden to Britain's welfare system and labour market. The image conjured up here was also characterised by elision, played on in particular by

\footnotetext{
3 This understanding of 'affective-discursive structures' builds on Raymond Williams' (1977) concept of 'structures of feeling' as well as the more recent literature on the 'affective turn' in social theory (Clough 2007). My concern is with the ways in which certain discourses attach themselves to affects and render them intelligible. This is similar to Wetherell's (2015, p. 1152) use of the term 'affective-discursive practices' to refer to activities through which emotional sense of the social world is generated. I refer to affective-discursive structures rather than a more amorphous notion of moods, environments or atmospheres as is prominent in the literature associated with the affective turn (cf. Anderson 2009) in order to emphasise the coherent patterns of feelings and the discourses attached to them that in turn render these feelings intelligible, thus shaping and organising the public sphere of politics.

4 'False' here is not a normative comment about whether Brexit is right or wrong, but pertains to the analytical argument that Brexit is advocated as a solution to social and economic problems in Britain that a departure from the EU in and of itself cannot solve.
} 
the UK Independence Party's Nigel Farage who forced a symbolic convergence of EU migration with the Syrian refugee crisis in the minds of voters, linking this in turn to anxieties over Islamist terrorism. Second, social and economic inequality and lack of resources. This was iconically captured in the proposal that the UK's EU-membership funds (alleged at $£ 350$ million a week) could instead be spent on Britain's National Health Service (NHS). Here the NHS had a simultaneous function as a positive and negative signifier: the NHS is both the symbol of postwar British national pride as well as the symbol of a crumbling underfunded public welfare system. Third, a feeling of loss of control, where everyday feelings of disempowerment were condensed into the demand for regaining parliamentary sovereignty by exiting the European Union, resonant in the now familiar slogan "Take back control" (Goldsmith 2017). Fourth, a sense of lack, loss, threat, inequality and decline, resonant in the word 'back'. 'Back' is rhetorically powerful, precisely because it is an empty signifier that can mean different things to different people, as long as they are susceptible to its affective drive. Although the phenomenon of Brexit is not reducible to right-wing populism, these four elements are standard in the kind rightwing populism that has emerged across advanced capitalist societies in response to the crisis of neoliberal globalisation (Wodak 2015; Wodak and Krzyżanowski 2017; Hameleers 2019).

\section{Rallying around remain}

The affective-discursive structure of Remain prior to the 2016 referendum was shaped by a more demobilising affect of maintaining the status quo. Where the Brexit campaigns mobilised anger and the desire for change, the Remain campaigns were dubbed 'Project Fear' (Jack 2016) in an allusion to the official Remain campaign's insistence that leaving the EU would result in economic disaster for the UK, with high-profile economist and politicians issuing statements to this end that even included Nobel Laureate economists and the then US President Barack Obama (O'Sullivan 2016). ${ }^{5}$ Rather than offering a positive vision of EU membership, the message merely affirmed the status quo as 'better the devil you know' (Goldsmith 2017). Progressive social movements long critical of the neoliberal policies of the European Union mobilised with the message, Another Europe is Possible, imploring voters to opt for staying in the European Union, without really offering much by way of enthusiasm or concrete ideas of how another better Europe might actually be brought about. ${ }^{6}$ Indeed, upholding a critical distance to the neoliberal policies of the European Union while calling on the electorate to vote to stay in the EU in order to avert something worse-even more neoliberal deregulation labour and environmental standards in a Brexit Britain no longer kept in check by the EU-was a complicated message to sell. And while there were of course many Brits who passionately believed in staying in the EU, it was more likely that on the Remain side

\footnotetext{
5 https://www.theguardian.com/politics/2016/jun/19/we-nobel-prize-winning-economists-believe-theuk-is-better-off-in-the-eu; see also: https://economistsforremain.org/. Accessed 7 January 2021.

6 https://www.anothereurope.org/. Accessed 7 January 2021.
} 
supporters were less active because they expected the status quo of EU membership to prevail. This included many young people for whom EU membership was not a political battle they actively identified with, even though they felt politically disaffected. The latter in part also explains the low turnout among young voters (Sloam and Henn 2019). These factors made it an uphill struggle for Remain campaigners to get more people actively involved in opposing the political efforts of Brexiteers. It is only after the shock of the Brexit vote that an explicitly pro-EU movement regularly organising protests in favour of Remain comes into existence. ${ }^{7}$ Nonetheless, this new 'movement of the $48 \%$ ' has no clear agenda for how to address the changes that are needed not just in Britain, but also in the EU. All in all, a vote to remain in the EU was nothing more than a vote against Brexit and everything that Brexit implied, than it was an explicit vote in favour of the EU.

\section{The crisis of neoliberal globalisation}

Since the 1970s, Britain has been characterised by deindustrialisation and uneven regional development, increased dependency on the service economy in general and financial services in particular, as well as welfare state retrenchment along with labour market deregulation and polarisation. After the Global Financial Crisis of 2008, this was exacerbated by a combination of austerity measures, regressive taxation and quantitative easing. The result has been that only those at the very top of society have managed to immunise themselves from economic crisis. The term the 'squeezed-middle' marks a new dividing line that reaches into segments of the population who once considered themselves relatively secure and are now struggling, while it is the most disadvantaged people in Britain who have borne the brunt. In 2019, 22 per cent of the population were living in relative poverty (after housing costs) (Frances-Devine 2019, p. 10). Particularly affected are people from Black and Minority Ethnic groups, people with disabilities, single mothers and female pensioners living alone (Ginn 2013; Runnymede Trust 2017, p. 4; Ryan 2019). Moreover, councils in parts of England affected by deindustrialisation were hardest hit by cuts, driving a wedge between those cities and regions that can afford services and those that cannot (Gray and Barford 2018; Tinson et al. 2018).

Monetary policies such as quantitative easing have led to asset price inflation, favouring those who own financial assets (Green and Lavery 2015). Increases to personal tax allowances as well as higher rate tax allowances benefit affluent citizens, because less of their income is taxed. Value Added Tax (VAT) is now more important than income tax as a major source of government revenue and increases to VAT in 2010 have placed a greater burden on lower-income groups, because they spend more of their income on VAT-rated goods (ONS 2011). At the same time, continued reductions in corporation tax are making taxes on business less relevant (TaylorGooby 2016, p. 718). Corporation tax receipts forecast to amount to a mere 2.3 per cent of national income by 2021-22, down 1 per cent (Miller 2017). Overall, two

\footnotetext{
7 https://www.theneweuropean.co.uk/; see also: https://www.bbc.co.uk/news/av/business-36660075. Accessed 7 January 2021.
} 
significant shifts in government revenue-raising are occurring: from the wealthier to the poorer and from businesses to individuals (Taylor-Gooby 2016, p. 719).

Household indebtedness has also risen, while the trend towards greater financialisation of the economy has intensified. In 2017, overall household debt comprised $87 \%$, compared to just under 30\% in 1980 (IMF 2019). Recent pension reforms have actually cost the state more in the short term, yet they cohere with the vision of Britain as a finance-led economy (Berry 2016). Similarly, the trebling of university tuition fees since 2010 leaves graduates with tens of thousands of pounds of debt in the form of student loans (McGettigan 2013). These developments constitute a significant shift towards asset-based welfare, especially through mortgages and homeownership (Finlayson 2009). Individuals and households have become much more directly connected to the financial services industry, thus exposed to the vicissitudes of global financial markets and risks of economic downturn (Bryan and Rafferty 2018, p. 192-196). Overall there has been a restructuring of class relations along the lines of debt, access to credit and asset ownership. This has fostered new divisions and exclusions where neoliberal globalisation has failed to deliver on the promise of inclusive and meritocratic prosperity (Mason 2011; Lazzarato 2012).

\section{The social structure of the Brexit vote}

It is into this crisis of neoliberal globalisation that the Brexit Complex inserts itself, whereby the socio-demographics of the Brexit vote show that age, education, ethnicity and social class mattered. ${ }^{8}$ In other words, the older someone was and the less educated they were, the more likely it was that they voted for Brexit; so too, being working class and white made it more likely that someone voted for Brexit. Yet, this does mean that all these social structural attributes congealed in a single bearer of Brexit. Nor did everyone in the above categories vote for Brexit; a cast of characters can be identified that cut across the dividing lines of class.

\subsection{The 'left-behind'}

Using the social grade schema used in British electoral analyses, we see that $64 \%$ of C2 voters voted for Leave (skilled manual workers), as 64\% DE voters (semiskilled and unskilled manual workers; state pensioners, casual and lowest grade workers, unemployed persons), as did $51 \% \mathrm{C} 1$ voters (supervisory, clerical and junior managerial, administrative and professional) and $43 \% \mathrm{AB}$ voters (Higher managerial, administrative and professional, intermediate managerial, administrative and professional). ${ }^{9}$ Evidently, a large proportion of non-working and working

\footnotetext{
8 This article uses the Lord Ashcroft Polls, which surveyed voters after they had voted: https:// lordashcroftpolls.com/2016/06/how-the-united-kingdom-voted-and-why/. Accessed 7 January 2021. The numbers vary slightly from the Essex Continuous Monitoring Surveys Pre-Referendum Survey in June 2016, used for example in the analysis of H. Clarke et al. (2017). However, the overall thrust is the same in both polls.

${ }_{9}$ See https://lordashcroftpolls.com/2016/06/how-the-united-kingdom-voted-and-why/. Accessed 7 January 2021.
} 
class voters voted for Brexit - these are voters in the categories C2, D and E. ${ }^{10}$ These voters have been variously labelled the 'left-behind', the 'left out' or the 'losers of globalisation' and are considered to have voted for Brexit out of protest against neglect and marginalisation. Predominantly, but not exclusively, they live in regions affected by deindustrialisation in the North and South West of England (Davies 2016). They have experienced a long protracted process of social and economic exclusion for which Brexit is merely the latest episode (Hazeldine 2017). This also explains the immunity to warnings of major economic risk posed by voting to leave the EU propagated by the official Remain campaign, in turn corroborated in qualitative interviews with working class voters and in quantitative correlations between voting leave and not considering economic risk to be of relevance (McKenzie 2016; Delanty 2017, p. 114; H. Clarke et al. 2017, p. 170).

\section{2 'The squeezed-middle'}

Further research has looked at the considerable numbers of middle-class Brexit voters, especially in the South-West and rural parts of England. This research has criticised the overemphasis on the working-class vote and argues that analyses need to factor in the high proportion of middle-class voters and the low turn-out among working-class voters (an indicator of political disaffection). Dorling $(2016,2018)$ has argued that actually $59 \%$ of voters were middle-class or higher ( $\mathrm{AB}$ and $\mathrm{C} 1$ ), $41 \%$ were working-class (C2) and only $24 \%$ were in the lowest two social grades (DE). Taking on board Dorling's concerns, albeit without dismissing the working class Leave vote, it must be acknowledged that the electoral picture is more complex than attributing responsibility for Brexit with the most economically disadvantaged in Britain.

Considering these factors, Antonucci et al. (2017) conducted qualitative interviews with Leave voters whose self-identification was middle-class. Their research revealed in particular the concerns over the deterioration of voters' personal financial situation in the five years prior to being interviewed. These voters expressed considerable anxiety over their own social vulnerability and over economic decline. Academic literature often posits this as status anxiety (Nachtwey 2016). However, these are people particularly affected by the economic fall-out of the Global Financial Crisis and in particular the major austerity measures since 2010. They are voters more recently disaffected by the end of the promise of social mobility, especially in regions and in older age groups where dramatic cuts to social care have taken their toll.

\section{3 '(Elite) imperial nostalgia'}

Nonetheless, the Brexit vote was not simply a cry of outrage by the 'left-behind' or the 'left-out' against the establishment. Among middle-class and upper middle-class

10 This is the National Readership Survey (NRS) schema, which attributes a social grade based on occupation (http://www.nrs.co.uk/nrs-print/lifestyle-and-classification-data/social-grade/. Accessed 7 January 2021.). 
Brexit-voters were those who were not struggling economically, but nonetheless unhappy with the Cameron government. This correlates with the prevalence of homeownership among Leave voters, the significance of age, but also the strong cultural conservatism of the Leave vote. ${ }^{11}$ This would also explain the Leave vote in wealthier parts of rural England (Dorling 2016). These Leave voters would have been less convinced by the outright xenophobic rhetoric of Nigel Farage and more convinced by the prominent figure of the other Leave campaign, Boris Johnson (Cummings 2017). Indeed, psephologists have identified a statistically significant 'Boris effect' in the analysis of the vote (H. Clarke et al. 2017, p. 170ff.).

Dorling and Tomlinson (2019) have suggested that the appeal among older conservative middle-class voters, as well as an elite, constitutes what they view as 'imperial nostalgia', stressing the importance of an imperial education among those who went to school before the 1970s, but also and especially among elites who held a worldview that did not fit with the idea of Britain tethered to the rules and regulations of the European Union and unable to go its own way. Here, then, is another kind of rhetorical "back". Not back to industrial England, not back to the securities of social mobility, but back to the kind of global standing that Britain had in the past.

Certainly, there is long-standing EU-scepticism within the British establishment and positions on membership have historically long divided opinions within the Conservative Party (Jessop 2016). Indeed, Brexit can be viewed as the gaining of political power of the faction of the Conservative Party who wished to see "Britannia Unchained" (Kwarteng et al. 2012) from the rules and regulations of Europe, such that Britain could be free from the problems of the Eurozone crisis and forge an economic renewal based on more, not less, globalisation and liberalisation outside of the European Union (Worth 2016). ${ }^{12}$ No doubt, the idea that a "Global Britain" (May 2016) should once again be an "independent free-trading nation" (Fox 2019), emphasised by Brexiteers, is reminiscent of the kind of imperial gesture that Dorling and Tomlinson are driving at. It also has echoes of an English nationalism that lays claim to leading the Union (of the United Kingdom) and is bound up with British colonial history. As Wellings (2016, p. 370) explains: "Defending British sovereignty against European integration-and the consequent search for an alternative political community-sustains the British and imperial element of a politicised English imagination, blurring the boundaries of English nationhood." English national identity did not determine the vote for Leave, yet a latent relevance is apparent where analysis finds that identifying as English rather than British was linked to attributing more benefits with Brexit than costs (H. Clarke et al. 2017, p. 168).

Edgerton (2020) argues that it is actually not imperialism and the British Empire at all that motivate Brexit for much of the electorate, but nostalgia for a national

\footnotetext{
11 On the significance of home ownership, see H. Clarke et al. (2017, p. 151); on the significance of cultural conservativism, see the Ashcroft polls at https://lordashcroftpolls.com/2016/06/how-the-united-kingdomvoted-and-why/. Accessed 7 January 2021.

12 Britannia Unchained is the title of a book published in 2012 by a group within the Conservative Party who argue for more trade liberalisation. They are ideological advocates of free trade and embrace a Thatcherite legacy. Nearly all of them currently hold positions within Prime Minister Boris Johnson's cabinet.
} 
postwar Britain linked to ideas of the welfare state and the 1962 repealing of the 1948 Commonwealth Citizenship Act due to racialised anxieties. The structural racism of British society was a key element of Brexit, articulated explicitly in concerns over immigration expressed by Brexit voters (H. Clarke et al. 2017, p. 173). In the immediate weeks after the EU-referendum there was a sharp increase in reported cases of racist abuse and attacks across the UK that people commented on as reminding them of Britain in the 1980s (Turner 2016), even if in the medium-term post-referendum attitudes towards immigration have softened (Ford 2018; Blinder and Richards 2020) - a point I return to in conclusion. The political salience of immigration for the referendum renders another kind of rhetorical 'back' intelligible. Shilliam (2018, p. 156) argues that the idea of 'imperial nostalgia' does not quite hit the mark and suggests instead that what is at play is 'melancholic racialised nationalism'. He states that it is "more historically accurate to place the sentiment of being 'left behind' within a defence of the national compact at one point granted white workers an institutionally advantaged position, with some still today enjoying its legacy benefits, for example, occupational pensions." Evidently, looking 'back' to find the explanation for the Brexit vote requires a precise demarcation of the point in British history that is being looked back to.

\section{The residue of a postwar class-compromise}

Making sense of the Brexit Complex requires refraining from analyses that insist on one prime mover being the driving force, be this the left-behind working class, the left-out middle class, the Eurosceptic nostalgic elites, English nationalism or racism per se. Instead the constellation of voting patterns must be interpreted. Brexit was a vote by disaffected segments of the population. However, not everyone who felt disaffected voted for Brexit. Those who voted out of disaffection together produced the Brexit vote, but their disaffections were not rooted in the same motivations or lived social experiences. There is an accumulation of grievances, tensions and contradictions that culminate in the Brexit vote and form contradictory cross-class alliances.

In fact, the two Brexit campaigns did not actually intend to speak to a particular social group, demographic or political ideology. While there was an explicitly rightwing Brexit campaign spearheaded by Nigel Farage, as well as a much smaller contingent of left-wing Brexiters ('Lexiters'), the official Leave campaign did not seek to appeal either to left-wing or right-wing voters per se. Instead it sought to channel the different disaffections across the electorate. Dominic Cummings, key strategist in the Leave campaign and subsequently a key advisor to Prime Minister Boris Johnson, has explained that the efforts to bring the electorate on board with Brexit focussed on galvanising political disaffection with regard to three central political issues that-on the basis of focus group discussions conducted with cross-sections of electorate-Leave campaigners learned were of concern. These were immigration, rising inequality following the 2008 Global Financial Crisis, the sovereign debt crisis in the Eurozone and the EU leadership's treatment of countries like Greece (Cummings 2017). The aim was to tap into the different voter grievances 
and link them to Brexit as a way of giving political meaning (and resolution) to these frustrations.

And yet, the constellation of the Brexit vote was not entirely random. A crossclass alliance begins to make sense if we see it as the residue of the social democratic post-war class-compromise of Fordism-Keynesianism with its organising principles of family, work and nationhood (F. Williams 1991). It included full employment, expanded consumption, social mobility and rising living standards, access to the welfare state and home-ownership in a property-owning democracy; it involved a social security system, provision of public goods and the regulation of the excesses of capitalism upheld by the purchasing power of consumers, productivity gains and strong economic growth (cf. Jessop 1989; Wright 2012; Pineault 2016). With its male breadwinner model, denial of social security assistance to dependent wives and the reliance of women's unpaid reproductive labour in the home, along with the patriarchal social relations of power that upheld such arrangements, it was gendered (F. Williams 1991). And where this Fordist-Keynesian class compromise also relied on the exploitation of migrant labour, including workers from the Commonwealth who came to Britain as citizens, but whose labour was viewed as inferior through the constructions of nationhood and moral superiority (Bhambra 2016), it was also racialised.

Neoliberal globalisation dismantled this postwar class compromise: a combination of globalisation and financialisation eroded and undermined it without establishing a new class compromise as a stable basis for capital accumulation and economic growth, evident in the failures and betrayals of New Labour's neoliberal turn. It is this residual class compromise and attempts at its reactivation as a way of dealing with the present crisis that explain the cross-class alliance of the Brexit vote. However, today's conditions are very different, evident precisely in the constellation of forces on the other side of the vote.

\section{The social structure of remain}

The dominant characterisation of the Remain vote is that it encompassed progressive elites motivated by liberal cosmopolitan values who, in economic terms, are on the winning side of neoliberal globalisation. The Remain vote was comprised as follows: $57 \%$ AB voters, $49 \%$ of $\mathrm{C} 1$ voters, $36 \% \mathrm{C} 2$ and $36 \%$ of DE voters. ${ }^{13}$ Certainly, the Remain vote included neoliberal elites and a sizeable portion of the professional and managerial class who could indeed be considered the beneficiaries of neoliberal globalisation. However, it does not necessary follow that the vote for Remain was entirely dominated by the 'winners of globalisation' any more than Brexit was simply comprised of neoliberalism's losers. This is apparent in three significant markers of the Remain vote, namely ethnicity, geographical region and age.

\footnotetext{
13 https://lordashcroftpolls.com/2016/06/how-the-united-kingdom-voted-and-why/. Accessed 7 January
} 2021. 


\subsection{Ethnicity}

Ethnic minority voters were overwhelmingly pro-Remain: $73 \%$ of non-white voters eschewed the vote for Brexit (Emejulu 2016; Alabrese et al. 2019, p. 141). This number includes a non-white working class in Britain that was significantly less likely to vote for Brexit given the racists overtones of the Brexiteers, despite also experiencing significant economic inequality and hardship. As aforementioned, many working people and a significant number of poor and socially excluded people in Britain belong to Black and Minority Ethnic groups. 'Methodological whiteness' (Bhambra 2016) problematically obscures that British society in general and the working class in particular is multi-ethnic, and indeed that poverty and deprivation in Britain are not exclusively, but significantly racialised.

However, disaggregation of ethnic minority voting offers evidence for British South Asian support for Brexit, including among the better-off (Abbasi 2016; Ehsan 2017). To date there is no academic research that further probes the reasons for this. Ehsan suggests that identification with Europe and EU-migrants may simply not be significant for British South Asians. He also suggests that British South Asians may well have been persuaded by the pro-Commonwealth rhetoric of the Leave campaign and the assertions of Michael Gove that the EU was forcing Britain to privilege EU migrants at the expense of others, including people from Commonwealth countries (incidentally, a similar argument in the name of internationalism was indeed also made by left-wing Brexiters). ${ }^{14}$ Consequently, the story may not simply be one of whiteness. While it is necessary to understand the ways that racism and xenophobia were mobilised in the campaign, the problematic cannot be reduced to ethnic identity in general, but requires concrete historical contextualisation.

\subsection{Geographical region}

There was above-average support for Remain among city dwellers, especially in London and in university towns (Hazeldine 2017, p. 51; Sloam and Henn 2019, p. 78). Urban centres are much more ethnically diverse and voters are more likely to live and work with people from different ethnic backgrounds, which diminishes rather than heightens xenophobia. This argument is corroborated by the fact that those regions in the UK with the fewest migrants (defined as people born outside the UK) are regions with some of the highest numbers of votes for Brexit (Lawton and Ackrill 2016). This is the case even though there were areas outside of London and the larger cities with a particularly stark increase in EU migration (i.e. very rapid social change) and a high percentage of Leave votes (Hazeldine 2017, p. 69). Moreover, urban centres attract more young people looking for the educational and occupational opportunities that cities offer.

\footnotetext{
14 See http://www.leftleave.org/. Accessed 8 January 2021.
} 


\subsection{Age}

Among the 18-30 year-olds, 69\% voted for Britain to remain in the European Union. Among the 18-21 year-olds, this figure even rises to 76\% (Ehsan and Sloam 2018, p. 48). Disaggregated by age, the data reveal that it is young women in particular who are the most pro-Remain group of all (Sloam and Henn 2019, p. 12). This is noteworthy, because gender is statistically insignificant in the overall vote (Ashcroft 2016; H. Clarke et al. 2017). ${ }^{15}$ Nonetheless, only a third of young people actually turned out to vote, which has led analysts to conclude that there could have been a much larger proportion of votes for Remain had more young people voted (Dorling and Tomlinson 2019, p. 65). Here, a similar issue with regard to voter turnout and political disaffection arises as with the working-class vote. The more important issue, however, are the socio-economics of age and how they map onto Brexit's purported divide between globalisation's alleged winners and losers. Many young people, even before Brexit, faced a future in which they would be less welloff than their parents. Therefore, they cannot be said to be wholly globalisation's 'winners'. Many of them simply know nothing else other than high university fees, a crumbling public infrastructure, precarious employment and a flexibilised and insecure life. Yet, culturally, they are much less likely to be swayed by localist or traditional mindsets (which can include racist and sexist attitudes), having grown up in the era of globalisation's cosmopolitan 'progressive neoliberalism' (Fraser 2017).

Young people have also been disadvantaged by the aftermath of the financial crisis through a hostile labour market and large cuts to public spending (OECD cited in Ehsan and Sloam 2018, p. 47). Overall, economic circumstances in Britain have been becoming "increasingly divided along the lines of age, with younger adults experiencing less security and smaller [...] living standards improvements [with] much more cohort-on-cohort wealth progress for those born before the 1960s than those born since" (Gardiner et al. 2020, p. 7-8 and 17). The generation born between 1981 and 1985 have a quarter less total net wealth at the age of 34 than those born ten years before had at the same age. Underscored by weak pay growth and labour market segmentation, this trend emerged prior to the Brexit referendum and has continued in the years since. A rising proportion of 18-29 year olds work in low-pay sectors such as retail, hospitality and leisure where there is more precariousness and insecure employment, including zero-hours contracts in sectors such as education, retail, hospitality, health and social care as well as agriculture (a type of employment contract in which employers do not guarantee their employees hours and often expect them to work at very short notice, often also denying holiday and sick pay). They are prevalent among young, migrant and Black and Minority Ethnic workers (Farina et al. 2020).

Millennials (i.e. individuals born between 1981 and 2000) spend more than twice as much on rent as the generation before them did at the same age (Resolution Foundation 2016). The fact that the previous generation also spent twice as much on rent as the baby boomer generation before them (Ibid.) reveals a trend here.

15 Further qualitative research would be required here to probe the rationale(s) of young female voters with regard to Brexit. 
While the generation of the post-war class compromise were able to buy property and therefore augment wealth, today's young adults are excluded from this option due to rising house prices, wage stagnation and indebtedness underscored by the cost of university and of needing to buffer intermittent and precarious employment (Milburn 2019; Davies 2020). This is the case unless they are financially supported by parents in ways that consolidate and pass on economic and cultural capital from one generation to the next (cf. Bourdieu 1986). While the inheritance of wealth as a mechanism for the reproduction of privilege and social closure is nothing new, what is new is the growing relevance of asset price inflation for class relations under conditions of financialised capitalism (Adkins et al. 2019, p. 14).

Being in full-time education made it highly likely that someone voted Remain, evident also in the prevalence of the Remain vote in university towns. Certainly, students at higher education institutions would have been more exposed to a Remain perspective and therefore to liberal-cosmopolitan values (Sloam and Henn 2019, p. 78). However, where educational status is singled out as a marker of privilege, there are outdated assumptions about class at work that link university education with high social status. The postindustrial expansion of higher education means that a lot more of young people now gain university degrees: where in 1997 no more than $25 \%$ of those aged 25 to 34 held undergraduate degrees, by 2019 this figure had risen to over $50 \%$. Britain is one of the countries with the highest tertiarylevel educational attainment (OECD 2020). ${ }^{16}$ While the top universities remain elite bastions, a significant stratification of universities has occurred in order to enable university education for more of the population. This included the 1992 conversion of Polytechnics to ('new') universities. ${ }^{17}$ Many young graduates face precariousness and difficult job prospects and the majority are saddled with large debts. According to UK government figures, the average debt of a university graduate in 2018 was $£ 36,000$ (40,000 Euros), although the government only expects $30 \%$ of these graduates to ever be able to repay their loans (Bolton 2019, p. 3). Today there is a growing class of precarious workers who may well have recourse to cultural capital, but are economically insecure (Savage et al. 2013).

\section{Class relations reconfigured by neoliberal globalisation}

Neoliberal globalisation propelled a process of class recomposition that rested on post-1989 triumphalism and Thatcherite TINA, which presented neoliberal globalisation as inevitable and immutable. ${ }^{18}$ After the 1997 election of Tony Blair, New Labour increased welfare benefits and employment opportunities in an expanding public service sector. However, public service expansion was premised upon privatisation and marketisation, especially in deindustrialised parts of the country (Hazeldine 2017, p. 76). It was also coupled with workfare (Peck 1998), labour market

\footnotetext{
16 The figure is $40 \%$ in Austria and $33 \%$ in Germany (Ibid.).

17 Polytechnics were higher education institutions more likely to focus on technology and engineering subjects and professional/vocational degrees.

18 TINA is an acronym referring to 'there is no alternative' (to neoliberalism).
} 
activation and the heralding of entrepreneurism. New Labour shifted neoliberalism's previous social conservatism towards progressive values such as multiculturalism, feminism and gay rights, connecting these to consumerism and competitive labour markets (McRobbie 2016; Fraser 2017). In terms of class, neoliberal globalisation precipitated a recomposition. Postindustrial Britain has seen the emergence of new middle-class formations of professional and managerial workers along with new working-class formations of precarious workers, including young people, women, and people of colour (J. Clarke 2020b, pp. 122-123), coupled with the rise of new employment conditions that include the aforementioned zero-hours contracts.

If the Brexit vote was characterised by a residue of the postwar class compromise of social democracy, then the Remain vote was made up —at least in part—by those for whom it had no affective pull, given that they were either excluded from it in the first place, or because they were too young to remember anything other than what they knew of their present predicaments.

Precarious migrant workers, the younger generation and people belonging to Black and Minority Ethnic groups are part of the underside of a new professional class and neoliberal elites. Yet, if eligible to vote, most of them voted for Remain, the alleged side of globalisation's 'winners'. In other words, the disjuncture of Brexit is the residue of a postwar social democratic compromise versus an emergent class recomposition of neoliberal globalisation. Part of this class recomposition is a new rift between economic and cultural capital (Savage et al. 2013), growing precariousness, the continued racialisation of poverty and new intergenerational divides in which debt shapes class relations.

\section{Conclusion}

This article has revisited the sociological analysis of the outcome of the UK's EU-referendum in 2016, arguing that it requires an analysis of the social structural determinants of the votes for Leave and Remain. I have called into question simplistic readings that treat materialist and culturalist explanations as separate or even as conflicting interpretations of events. I depart from assumptions of class as social identity overdetermined by particular historical conjunctures to offer a dynamic account of the ways in which classes are made, unmade and remade in historical processes linked to developments in the global political economy, while attending to the cross-class alliances that emerge and become politically relevant. While the phenomenon of Brexit is specific to the particularities of Britain, it is linked to general transnational trends. I argue for a compositional and intersectional class analysis of the voter constellation on either side of the vote, in an understanding of how cross-class alliances are formed in the political arena to produce electoral (and policy) outcomes. Moreover, I suggest that such an analysis helps shed light on what is at stake in the ongoing crisis of neoliberal globalisation.

The outcome of the 2016 EU-referendum is the articulation of a divided country in which neoliberal globalisation has garnered a recomposition of class with 'winners' and 'losers' on both sides of the Brexit disjuncture. Brexiteers instrumentalised disaffection and appeased resentment, pitting those groups with the least social and 
economic power in society against one another. Since 2016, the pro and anti-Brexit camps in Britain have solidified into clear politicised identities, while the major parties remain divided over Brexit and struggle to coherently represent one or the other constituency. While the 'Generation Left' (Milburn 2019)_young Remain voters disaffected by both Brexit and the neoliberal status quo-voted for Jeremy Corbyn's left-wing political programme in the 2017 general election, in 2019 it was the loss of working class Labour heartlands to the Tories that catalysed the defeat of Corbynism, deepening political divisions on the Left over how to appeal to (working) class voters across the Brexit divide. Meanwhile, the Conservative party has reabsorbed UKIP voters and shifted further to the right under Boris Johnson and his pledges to 'get Brexit done'. Given the prominence of immigration as a driving issue of the referendum, it is striking that attitudes towards immigration have softened somewhat since then. It could be that media reports of a drop in net immigration offer reassurance to Leave voters concerned about immigration, while Remain voters may well have become (even) more positive about immigration as their pro-EU stance has consolidated (cf. Blinder and Richards 2020). Nonetheless, while the conflict over immigration may have become temporarily less politically charged, it is by no means resolved.

Post-Brexit, the British government under Prime Minister Boris Johnson is seeking ever-greater economic regulatory alignment with the USA in order to strengthen transatlantic relations. This signals a strong commitment to free trade and neoliberal deregulation, offering up Britain as a market for US products and services. Critics worry that this will occur to the detriment of social and environmental protections, harbouring nothing more than the prospect of greater authoritarianism and deeper division (Dearden 2020). It remains to be seen whether a viable resolution to the ongoing crisis will emerge that offers redress for social inequality and economic decline, while enabling new solidarities to be forged across the groups who are most adversely affected.

Funding Open access funding provided by University of Vienna.

Open Access This article is licensed under a Creative Commons Attribution 4.0 International License, which permits use, sharing, adaptation, distribution and reproduction in any medium or format, as long as you give appropriate credit to the original author(s) and the source, provide a link to the Creative Commons licence, and indicate if changes were made. The images or other third party material in this article are included in the article's Creative Commons licence, unless indicated otherwise in a credit line to the material. If material is not included in the article's Creative Commons licence and your intended use is not permitted by statutory regulation or exceeds the permitted use, you will need to obtain permission directly from the copyright holder. To view a copy of this licence, visit http://creativecommons.org/licenses/by/4. $0 /$.

\section{References}

Abbasi, Asad. 2016. Why Did South Asians Vote for Brexit? LSE Blog. November 3rd.

Adkins, Lisa, Melinda Cooper, and Martijn Konings. 2019. Class in the 21st century: asset inflation and the new logic of inequality. Environment and Planning A: Economy and Space https://doi.org/10.1177/ $0308518 \times 19873673$.

Alabrese, Eleonore, Sascha Becker, Thiemo Fetzer, and Dennis Novy. 2019. Who voted for Brexit? Individual and regional data combined. European Journal of Political Economy 56:132-150.

Anderson, Ben. 2009. Affective atmospheres. Emotion, Space and Society 2:77-81. 
Antonucci, Lorenza, Laszlo Horvath, Yordan Kutiyski, and André Krouwel. 2017. The malaise of the squeezed middle: challenging the narrative of the 'left behind' Brexiter. Competition \& Change 21(3):211-229.

Ashcroft, Michael. 2016. How the United Kingdom voted on thursday... and why, 24 June. https:// lordashcroftpolls.com/2016/06/how-the-united-kingdom-voted-and-why/. Accessed 22 Jan 2021.

Berry, Craig. 2016. Austerity, ageing and the financialisation of pensions policy in the UK. British Politics 11(1):2-25.

Bhambra, Gurminder. 2016. Brexit, Trump, and methodological whiteness: on the misrecognition of race and class. British Journal of Sociology 68(1):214-232.

Blinder, Scott, and Lindsey Richards. 2020. UK public opinion toward immigration: overall attitudes and level of concern. Briefing, January 20th, Migration Observatory at the University of Oxford.

Bolton, Paul. 2019. Student loan statistics. London: House of Commons Library. Briefing Article 1079.

Bourdieu, Pierre. 1986. Distinction: a social critique of the judgement of taste. London: Routledge.

Bryan, Dick, and Michael Rafferty. 2018. Risking together: how finance is dominating life in Australia. Sydney: Sydney University Press.

Clarke, John. 2010. Of crises and conjunctures: the problem of the present. Journal of Communication Inquiry 34(4):337-354.

Clarke, John. 2020a. Frustrations, failures and fractures: Brexit and 'politics as usual' in the UK. In Beyond populism-angry politics \& the twilight of neoliberalism, ed. Jeff Maskovsky, Sophie Bjork-James. New York: CUNY.

Clarke, John. 2020b. Building the "Boris" bloc_-angry politics in turbulent times. Soundings 74:118-135.

Clarke, Harold, Matthew Goodwin, and Paul Whitely. 2017. Brexit-why Britain voted to leave the European Union. Cambridge: Cambridge University Press.

Clough, Patricia. 2007. The affective turn. Durham: Duke University Press. with Jean Halley.

Crawford, Rowena, and Ben Zaranko. 2019. Tax revenues and spending on social security benefits and public services since the crisis. London: Institute for Fiscal Studies.

Cummings, Dominic. 2017. On the referendum \#21: branching histories of the 2016 referendum and "the frogs before the storm." Dominic Cummings's Blog 9th january. https://dominiccummings.com/2017/ 01/09/on-the-referendum-21-branching-histories-of-the-2016-referendum-and-the-frogs-beforethe-storm-2/. Accessed 8 Jan 2021.

Davies, William. 2016. Thoughts on the sociology of Brexit. In The Brexit crisis-A verso report, ed. Verso. London, New York: Verso.

Davies, William. 2020. Bloody furious. London Review of Books 42:4. 20th February.

Dearden, Nick. 2020. Trade secrets. London: Global Justice Now.

Delanty, Gerard. 2017. A divided nation in a divided Europe: emerging cleavages and the crisis of European integration. In Brexit: sociological responses, ed. William Outhwaite, 111-126. London: Anthem Press.

Dorling, Danny. 2016. Brexit-the decision of a divided country. British Medical Journal 354:i3697.

Dorling, Danny. 2018. Brexit and the radical right. Political Insight 9(4):36-39.

Dorling, Danny, and Sally Tomlinson. 2019. Rule Britannia-Brexit \& the end of empire. London: Biteback Publishing.

Dowling, Emma, Silke van Dyk, and Stefanie Graefe. 2017. Rückkehr des Hauptwiderspruchs? Anmerkungen zur aktuellen Debatte um den Erfolg der Neuen Rechten und das Versagen der „Identitätspolitik“. PROKLA 188(47, 3):411-420.

Edgerton, David. 2020. Britain's Persistent Racism Cannot Simply Be Explained by its Imperial History. The Guardian, 24th June.

Ehsan, Rakib, and James Sloam. 2018. Resources, values, identity: young cosmopolitans and the referendum on British membership of the European Union. Parliamentary Affairs 73(1):46-65.

Ehsan, Rakib. 2017. Inside the British Asian Brexit Vote-and Why it Contains a Few Surprises. The Conversation February 16th.

Emejulu, Akwugo. 2016. On the hideous whiteness of Brexit. In The Brexit crisis-A verso report, ed. Verso. London, New York: Verso.

Farina, Egido, Colin Green, and Duncan McVicar. 2020. Zero-hours contracts and their growth. British Journal of Industrial Relations 58(3):507-531.

Finlayson, Alan. 2009. Financialisation, financial literacy and asset-based welfare. British Journal of Politics and International Relations 11(3):400-421.

Flecker, Jörg, Gudrun Hentges, and Gabrielle Balasz. 2007. Potentials of political subjectivity and the various approaches to the extreme right: findings of the qualitative research. In Changing working life and the appeal of the extreme right, ed. Jörg Flecker, 35-61. Farnham: Ashgate. 
Ford, Rob. 2018. How have attitudes to immigration changed since Brexit? medium, january 24th. https://medium.com/@ robfordmancs/how-have-attitudes-to-immigration-changed-since-brexite37881f55530. Accessed 8 Jan 2021.

Fox, Liam. 2019. Britain's place in the global trading system. speech delivered at policy exchange in London. 1st february. https://www.gov.uk/government/speeches/britains-place-in-the-global-tradingsystem. Accessed 8 Jan 2021.

Frances-Devine, Bridget. 2019. Poverty in the UK: statistics. Briefing 7096. London: House of Commons Library.

Fraser, Nancy. 2017. The End of Progressive Neoliberalism. Dissent Magazine January 2nd.

Gardiner, Laura, Maja Gustafsson, Mike Brewer, Karl Handscomb, Kathleen Henehan, Lindsay Judge, and Fahmida Rahman. 2020. An intergenerational audit for the UK. London: Resolution Foundation (Intergenerational Centre).

Ginn, Jay. 2013. Austerity and inequality. Exploring the impact of cuts in the UK by gender and age. Research on Ageing and Social Policy 1(1):28-53.

Goldsmith, Paul. 2017. Why "take back control" trumped "project fear." UK in a changing Europe, November 23rd. https://ukandeu.ac.uk/why-take-back-control-trumped-project-fear/. Accessed 8 Jan 2021.

Gormley-Heenan, Cathy, and Arthur Aughey. 2017. Northern Ireland and Brexit: three effects on "the border in the mind". The British Journal of Politics and International Relations 19(3):497-511.

Gray, Mia, and Anne Barford. 2018. The depths of the cuts: the uneven geography of local government austerity. Cambridge Journal of Regions, Economy and Society 11:541-563.

Green, Jeremy, and Scott Lavery. 2015. The regressive recovery: distribution, inequality and state power in britain's post-crisis political economy. New Political Economy 20(6):894-923.

Hall, Stuart, John Clarke, Chas Critcher, Tony Jefferson, and Brian Roberts. 2015. Policing the crisis—mugging, the state, law \& order, 2nd edn., London: Palgrave McMillan.

Hameleers, Michael. 2019. Putting our own people first: the content and effects of online right-wing populist discourse surrounding the European refugee crisis. Mass Communication and Society 22(6):804-826.

Hazeldine, Tom. 2017. The revolt of the Rustbelt. New Left Review 105:51-79.

Hill-Collins, Patricia. 2009. Black feminist thought. London, New York: Routledge.

Hobolt, Sara. 2016. The Brexit vote: a divided nation, a divided continent. Journal of European Public Policy 23(9):1259-1277.

Inglehart, Ronald, and Pippa Norris. 2016. Trump, Brexit, and the rise of populism: economic have-nots and cultural backlash. HKS working paper no. RWP16-026. https://ssrn.com/abstract=2818659. Accessed 8 Jan 2021.

International Monetary Fund. 2019. Household debt, loans and debt securities—percent of GDP. IMF Data Mapper, imf.org.

Jack, Ian. 2016. "Project Fear" Started as a Silly Private Joke During Another Referendum, But Now It Won't Go Away. The Guardian, 11th March.

Jessop, Bob. 1989. Conservative regimes and the transition to post-Fordism: the cases of great britain and west Germany. In Capitalist development and crisis theory: accumulation, regulation and spatial restructuring, ed. Mark Gottdiener, Nicos Komninos. London: Palgrave Macmillan.

Jessop, Bob. 2016. The organic crisis of the British state: putting Brexit in its place. Globalizations 14(1):133-141.

Jones, Moya. 2017. Wales and the Brexit Vote. French Journal of British Studies https://doi.org/10.4000/ rfcb.1387.

Kaufmann, Eric. 2016. It's NOT the economy stupid—Brexit as a story of personal values. LSE Blog, July 7th 2016.

Knight, D. 2017. Anxiety and cosmopolitan futures: Brexit and Scotland. American Ethnologist 44(2):237242.

Koivisto, Juha, and M. Lahtinen. 2012. Conjuncture. Historical Materialism 20(1):267-277.

Kwarteng, Kwasi, Priti Patel, Dominic Raab, Chris Skidmore, and Elizabeth Truss. 2012. Britannia unchained - global lessons for prosperity and growth. London: Palgrave MacMillan.

Lawton, C., and Ackrill, R. 2016. Hard Evidence: How Areas With Low Immigration Voted Mainly for Brexit. The Conversation, July 8th.

Lazzarato, Maurizio. 2012. The making of indebted man: an essay on the neoliberal condition. Cambridge: MIT Press.

Mason, Paul. 2011. Why its kicking off everywhere-the new global revolutions. London, New York: Verso Books. 
May, Theresa. 2016. Prime Minister's Speech to the Lord Mayor's Banquet. 14th November. https:// www.gov.uk/government/speeches/pm-speech-to-the-lord-mayors-banquet-14-november-2016. Accessed 8 Jan 2021.

McGettigan, Andrew. 2013. The great university gamble: money, markets and the future of higher education. London: Pluto Press.

McKenzie, Lisa. 2016. EU Referendum: Many Don’t Care What Happens Next, They Just Wanted Change. Times Higher Education, June 24th 2016.

McRobbie, Angela. 2016. Be creative-making a living in the new culture industries. Cambridge: Polity Press.

Milburn, Keir. 2019. Generation left. Cambridge: Polity Press.

Miller, Helen. 2017. What's been happening to corporation tax? Briefing Note, 10 May, Institute for Development Studies, archived at ifs.org.uk.

Nachtwey, Oliver. 2016. Die Abstiegsgesellschaft - Über das Aufbegehren in der regressiven Moderne. Frankfurt am Main: Suhrkamp.

Office for National Statistics. 2011. Poorest households spending more on VAtable items than in 1986. webarchive.nationalarchives.gov.uk. Accessed 10 Feb 2021.

O’Reilly, Jacqueline, Julie Froud, Sukhdev Johal, Karel Williams, Chris Warhurst, Glenn Morgan, Christopher Grey, Geoffrey Wood, Mike Wright, Robert Boyer, Sabine Frerichs, Suvi Sankari, Akos RonaTas, and Patrick Le Gale. 2016. Brexit: understanding the socio-economic origins and consequences. Socio-Economic Review 14(4):807-854.

Organisation of Economic Cooperation and Development (OECD). 2020. Population with tertiary education (indicator). https://doi.org/10.1787/0b8f90e9-en.

O’Sullivan, John. 2016. Brexit After Obama. National Review, April 29th.

Peck, Jamie. 1998. Workfare: a geopolitical etymology. Environment and Planning D: Society and Space 16:133-161.

Pineault, Eric. 2016. No deal capitalism: austerity and the unmaking of the north American middle class. In Austerity - the lived experience, ed. B. Evans, S. McBride. Toronto: University of Toronto Press.

Resolution Foundation. 2016. Millennials have paid $£ 44,000$ more rent than the baby boomers by the time they hit 30. London: Resolution Foundation. Press Release 16 July 2018, Intergenerational Centre.

Runnymede Trust. 2017. Intersecting inequalities: the impact of austerity on black and minority ethnic women in the UK. Report by the Women's Budget Group, RECLAIM, Coventry Women's Voices and the Runnymede Trust. London: Runnymede Trust.

Ryan, Frances. 2019. Crippled-austerity and the Demonisation of disabled people. London, New York: Verso.

Savage, Mike, et al. 2013. A new model of social class? Findings from the BBC's great British class survey experiment. Sociology 47(2):219-250.

Shilliam, Robbie. 2018. Race and the undeserving poor-from abolition to Brexit. Newcastle upon Tyne: Agenda Publishing.

Sloam, James, and Matt Henn. 2019. Youth quake 2017-the rise of the young cosmopolitans. London: Palgrave McMillan.

Sunstein, Cass. 2009. Republic.com 2.0. Princeton: Princeton University Press.

Taylor-Gooby, Peter. 2016. The Divisive Welfare State. Social Policy and Administration 50(6):712-733, 722 .

Thompson, Edward Palmer. 1978. Eighteenth-century english society: class struggle without class? Social History 3(2):133-165.

Tinson, Adam, Carla Ayrton, and Issie Petrie. 2018. A quiet crisis: local government spending on disadvantage (executive summary). London: New Policy Institute.

Turner, Camilla. 2016. Spate of racist attacks blamed on Brexit vote. The Telegraph, 26 June. https:// www.telegraph.co.uk/news/2016/06/26/spate-of-racist-attacks-blamed-on-brexit-vote/. Accessed 22 Jan 2021.

Virdee, Satnam, and Brendon McGeever. 2017. Racism, crisis, Brexit. Ethnic and Racial Studies 41(10):1802-1819.

Wellings, Ben. 2016. Our island story: England, Europe and the anglosphere alternative. Political Studies Review 14(3):368-377.

Wetherell, Margaret. 2015. Trends in the turn to affect-a social psychological critique. Body \& Society 21(2):139-166.

Whitehead, Judith. 2016. Intersectionality \& primary accumulation. Monthly Review 68(6). https:// monthlyreview.org/2016/11/01/intersectionality-and-primary-accumulation/. Accessed 8 Jan 2021.

Williams, Fiona. 1991. Social policy: a critical introduction. Cambridge: Polity. 
Williams, Raymond. 1977. Marxism \& literature. Oxford: Oxford University Press.

Wodak, Ruth. 2015. The politics of fear: what right-wing populist discourses mean. London: SAGE.

Wodak, Ruth, and Michał Krzyżanowski. 2017. Right-wing populism in europe \& USA: contesting politics \& discourse beyond "Orbanism" and "Trumpism". Journal of Language and Politics 16(4):471-484.

Worth, Owen. 2016. Reviving Hayek’s dream. Globalizations 14(1):104-109.

Wright, Erik Olin. 2012. Class struggle and class compromise in the era of stagnation and crisis. Article presented at the Nicos Poulantzas institute, Athens, Greece in december 2011. https://www.ssc.wisc. edu/ wright/Class-Crisis-Stagnation.pdf. Accessed 8 Jan 2021.

Emma Dowling teaches at the Department of Sociology, University of Vienna. Her research interests include social change, global political economy, financialisation and society, welfare state transformation, work and emotions, participatory research methods. Her most recent publications include the monograph The Care Crisis (London, New York: Verso, January 2021) as well as the journal articles 'Confronting Capital's Care Fix: Care through the Lens of Democracy' (Equality, Diversity and Inclusion: An International Journal, 2018) und 'In the Wake of Austerity: Social Impact Bonds and the Financialisation of the Welfare State in Britain' (New Political Economy, 2016). 